\title{
Temporal Variability of Water Table Depth in Topohydrosequence of Undulating Ground Moraine in Central Poland
}

\author{
Michał Kozłowski*, Jolanta Komisarek, Katarzyna Wiatrowska \\ Poznań University of Life Sciences, Department of Soil Science and Land Reclamation, Poznań, Poland
}

Received: 18 September 2017

Accepted: 22 October 2017

\begin{abstract}
Our paper presents the results of determining temporal variability in the water table depth in topohydrosequence of Retisols/Luvisols and Phaeozems/Gleysols. Assessing temporal variability in the water table was done using geostatistical and statistical methods. The mean annual water table depth in soils occupying higher locations in the relief were determined by precipitation in the given and previous years, but in soils of footslope only by precipitation in a given year. Water table fluctuations were characterized by a clearly visible temporal structure and low values of random variability. The range of time correlation of water table was dependent on the relief and was shorter in soils located in lower parts of the topohydrosequence and longer in wells in the higher part. The contribution of the nugget effect in variance was also dependent on the location of wells on the slope. The obtained values of the fractal dimension (D) show a distinct relationship between $\mathrm{D}$ and the location of soil in the topohydrosequence. The values of multivariate analysis indicated that the statistical and geostatistical parameters applied to assess temporal variability of water table depth were dependent on the soil (well) location in the relief.
\end{abstract}

Keywords: geostatistic, water table, temporal variability, topohydrosequence

\section{Introduction}

Spatial and temporal variability in the water table depth is one of the most important features affecting plant cultivation, water management, and protection, as well as the formation of water and soil resources. Hence, much effort has been devoted to the issues of temporal as well as spatial water table variability.

Many authors have emphasized a relationship between the water table and groundwater level

*e-mail: mkozl@up.poznan.pl fluctuations and climatological parameters such as precipitation and temperature [1-7]. Cai and Ofterdinger [2], examining the relationship between soil morphology and water table depth, have found a correlation between the average annual water table depth and annual precipitation. Shi et al. [8] emphasized that it is difficult to find a direct relation between precipitation and the groundwater level because of the complex factors determining groundwater depth. Statistically significant relationships between climatic parameters such as rainfall and temperature and groundwater level have also been found by Almedeij and Al-Ruwaih [9]. Cai and Ofterdinger [7] have noted a rapid connection between groundwater table depth and a precipitation 
event. Aflatooni and Mardaneh [1] obtained a positive correlation between the average yearly groundwater level and the annual precipitation with the delay of the rainfall inflow to the groundwater table.

Many techniques (statistical, geostatistical, fractal, trend, etc.) have been developed to better understand the complicated system of an unconfined aquifer. Some authors have applied regression analyses, based on measured or deduced water table depths and soil characteristics, to predict either water table depth fluctuations or soil features [10-13]. In those studies, the average annual groundwater table depth and its fluctuations were identified, and according to many researchers [14-17], the depths and fluctuations were dependent on the location of wells in the relief. In other studies, the main objective was to investigate the temporal trends of groundwater levels [18-22].

Triki et al. [23] used principal component analysis (PCA) and cluster analysis (CA) of time series of groundwater levels to classify groundwater hydrographs in regard to identical fluctuation patterns. They pointed out that the PCA would be particularly useful for interpreting the data on groundwater level measurements. Brito Neto et al. [24] have also used the clustering technique to group the time series variation of the water levels and pointed out that cluster analysis would be particularly effective, accurate, and practical for interpretation of the data on groundwater level measurements. Little and Bloomfield [25], Rakhshandehroo and Amiri [26], and Yu et al. [27] have used the detrended fluctuation analysis (DFA) to study the fractal scaling of groundwater level fluctuations.

Since water level in an unconfined aquifer in nature is highly variable in both time and space, many authors have used the geostatistical techniques based on the theory of regionalized variables [6, 23, 28-31]. It should be added that geostatistics were used mainly to analyse the spatial variability in groundwater level fluctuations, and less attention was paid to analyzing the temporal variability in groundwater level. Only Triki et al. [23], Ahmadi and Sedghamiz [29], and $\mathrm{Ta}^{\prime}$ any et al. [31] have employed geostatistical analyses to better understand the dynamics of aquifer systems. They have used the semivariance function to evaluate the temporal variations in the groundwater level.

Among other studies that also focused on temporal analysis of groundwater using geostatistics, Ran et al. [32] have applied spatial and temporal geostatistical analysis to find the most appropriate groundwaterlevel monitoring network in the Zhangye Basin, China. Although geostatistics were used in some studies of temporal variability in the groundwater level, no

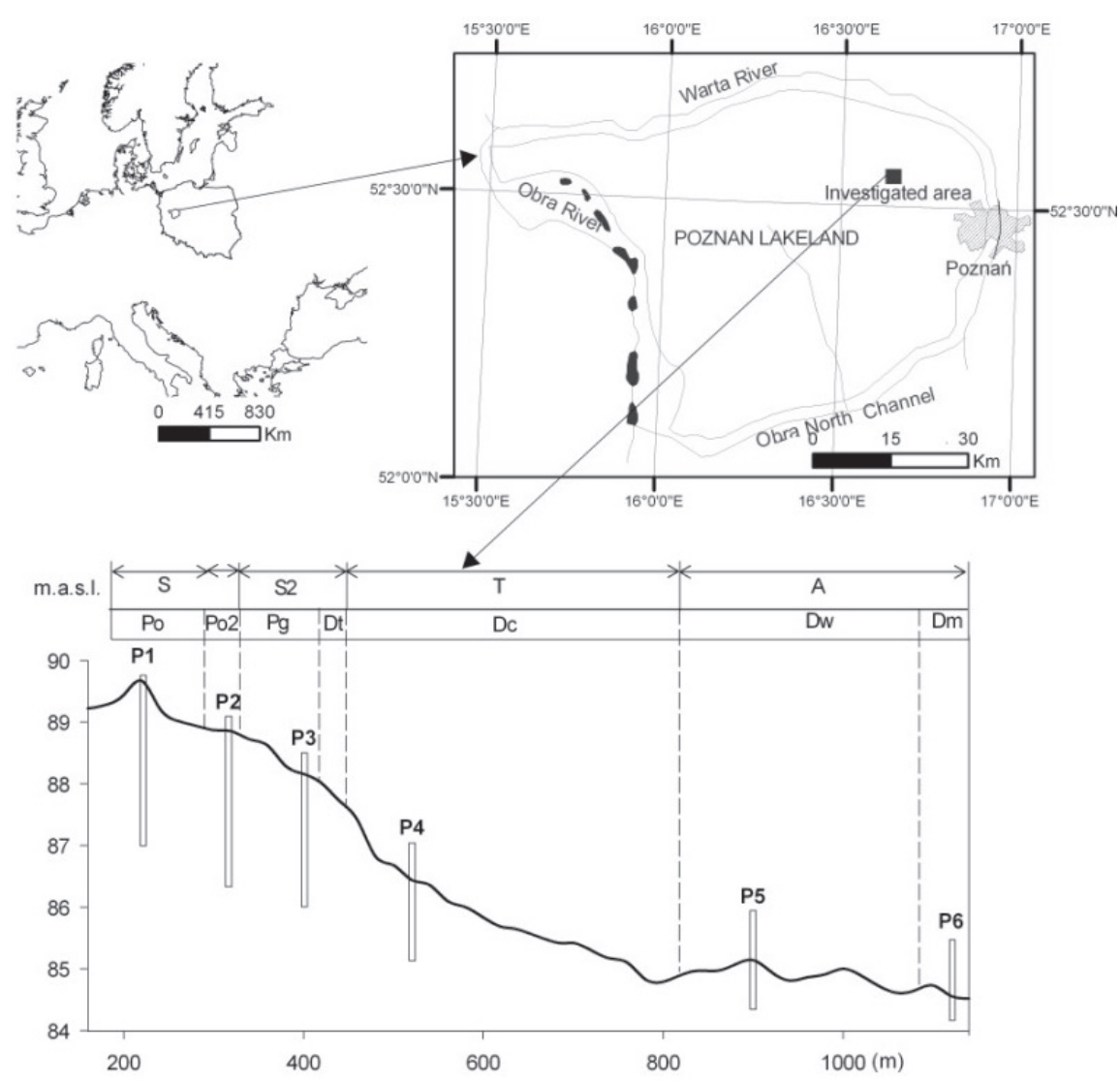

Fig. 1. Location of investigated area and distribution of wells in the soil catena: S- summit, S2- shoulder, T- pediment, A- footslope, Po- Eutric Albic Retisols (Loamic, Aric, Cutanic, Ochric), Po2- Albic Luvisols (Loamic, Aric, Cutanic, Ochric), Pg- Gleyic Luvisols (Loamic, Aric, Cutanic), Dt- Luvic Gleyic Phaozems (Loamic, Aric), Dc- Cambic Gleyic Endocalcic Phaozems (Loamic, Aric), DwCalcic Mollic Gleysols (Loamic, Aric, Drainic), Dm- Calcaric Mollic Gleysols (Loamic, Aric, Drainic, Humic). 
attention was paid to analyzing the temporal variability of groundwater level in the topohydrosequence.

In this study statistical and geostatistical analyses were applied in order to characterize temporal variability in the water table within the topohydrosequence. Detailed identification of the relationships between the soil location (wells) on the slope and dynamics of the water table can be a good starting point for modelling and optimizing both balanced plant production and protection as well as the formation of water and soil resources. Moreover, the analyses applied, especially geostatistics, make valuable support for management of monitoring and decisions made on the basis of temporal variations in the water table.

The aim of this study was to specify the variables that describe temporal differences in the water table within the topohydrosequence, and to check the correlation between these variables and the position of soil in a relief.

\section{Material and Methods}

\section{Study Area}

The study was carried out in the cultivated catchment area of the Przybroda Experimental Station located in the north-central part of the Poznan Lakeland (western Poland) within the Szamotuly Plain. The study area is between $52^{\circ} 30^{\prime} 16^{\prime \prime}-52^{\circ} 30 ' 52^{\prime \prime}$ north and $16^{\circ} 39^{\prime} 35^{\prime \prime}-16^{\circ} 39^{\prime} 53^{\prime \prime}$ east (Fig. 1). This area is part of an undulating ground moraine of the Poznan Phase of Vistulian Glaciation. In the geomorphological conditions of the Poznań Lakeland, the Retisols/Luvisols and the Phaeozems/Gleysols form characteristic soil sequences along slopes (topohydrosequences). These soil sequences occur not only in the Poznan Lakeland but also in all regions of the Polish Lowland. The mean annual precipitation of the Poznań Lakeland is $597 \mathrm{~mm}$, the mean annual real evapotranspiration is $495 \mathrm{~mm}$, and the average annual temperature is $8^{\circ} \mathrm{C}$. Fig. 2 presents the climatic data of the Poznan Lakeland according to Marcinek and Komisarek [33]. Since the beginning of the second half of March the curve of the real evapotranspiration (ETr) intersects the curve of precipitation (P), and up to mid-August ETr is greater than $\mathrm{P}$. Throughout the remaining time of the year $\mathrm{P}$ exceeds ETr, and this is the time when precipitation water can infiltrate and percolate through the unsaturated soil zone and supply water table. According to climatic data, the amount of water that can supply the water table annually is about $100 \mathrm{~mm}$.

\section{Soil and Sample Collection}

At the beginning of the study we determined soil cover variability of the catchment area and identified the categories of landscape positions according to the criterions of Hall [34]. Representative pedons were determined on the basis of detailed hydropedological studies. Along the slope, a transect 1,100 m long was demarcated. In the transect, every $20 \mathrm{~m}$ the soil pits were made and the soil morphological properties and soil classifications were determined. At the same time, soil samples from each horizon for laboratory analyses were taken. In addition we used 10 to 12 soil drills (between soil pits) to determine the range of occurrence of a given polypedon. Then, the locations of the representative pedons (6 pedons) were selected (Fig. 1). Representative pedon is a characteristic part of the soil cover that builds a particular polypedon [35]. The representative pedons constituting the stationary sites of measurements were instrumented with wells constructed of $80 \mathrm{~mm}$ polyvinyl chloride (PCV) pipe. The wells were installed using a hand auger and sealed with a shield tube at the ground surface to prevent surface water infiltration along the side of the well and rainfall from entering.

The study covered six stationary measurement pedons, i.e., Eutric Albic Glossic Retisols (Loamic, Aric, Cutanic) (P1, P2), Haplic Luvisols (Loamic, Aric, Cutanic, Hypereutric, Ochric, Oxyaquic) (P3), Gleyic Cambic Phaeozems (Loamic, Aric, Oxyaquic) (P4), Calcic Mollic Subaquatic Gleysols (Loamic, Aric, Drainic) (P5), and Mollic Subaquatic Gleysols (Loamic, Aric, Drainic, Pachic) (P6) [36] (Fig. 1). Except for P6, which was formed by varied fluvioglacial material, the parent material of investigated soils was a glacial till. Taxonomic diversity of soil is related to its position on the slope and thus with depth to the water table.

The water table depths in stationary sites were measured every 2 weeks from January 1993 to March 2012. It was the longest continuous seasonal investigation of the water table in the Polish Lowland topohydrosequence. At the same time, the meteorological data were collected for the area of study. A weather station was located in the Przybroda

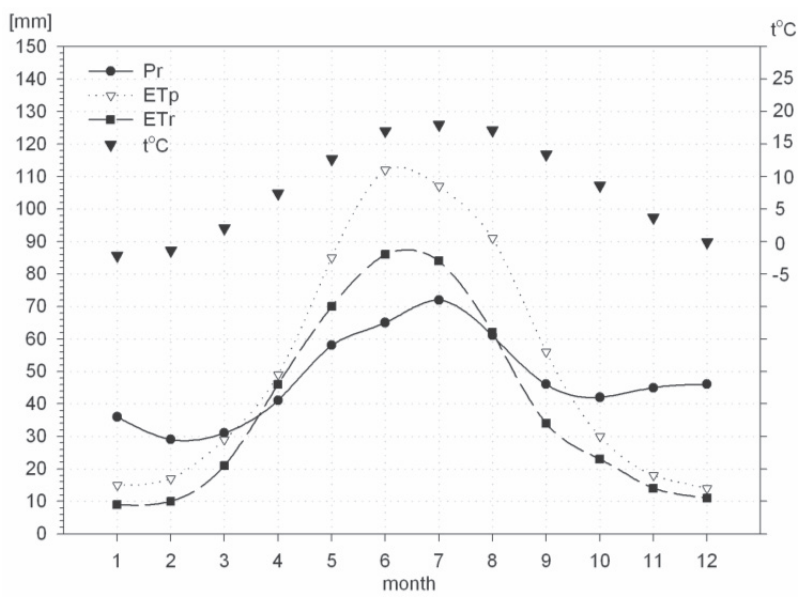

Fig. 2. Precipitation (P), potential evapotranspiration (ETp), real evapotranspiration $(E T r)$, and average temperature $\left(t^{\circ} \mathrm{C}\right)$ for the Poznań Lakeland [33]. 
Experimental Station about 1,100 $\mathrm{m}$ from the analysed topohydrosequence.

\section{Geostatistical and Statistical Analyses}

Temporal variability in the water table depth was determined using the geostatistical analysis in which the semivariance $\left(\gamma_{(k)}\right)$ is the basic function:

$$
\gamma_{(k)}=\frac{1}{2 \cdot n(k)} \sum_{i=1}^{n(k)}\left[z\left(x_{i}\right)-z\left(x_{i+k}\right)\right]^{2}
$$

...where $z\left(x_{i}\right)$ indicates the water table depth measured at time $i, z\left(x_{i+k}\right)$ is the water table depth measured at time $i+k$, and $n(k)$ is the total number of experimental pairs of observations separated by $k$ (temporal lag) [37]. Semivariance illustrates the degree of temporal dependence between water table depths, as a function of time $(k)$. Relations between values of semivariance and time correlation ranges were determined using the Variovin program [38]. The Gaussian variogram model was fitted to the experimental data in order to obtain the major parameters of the temporal water table variability. This model was chosen on the basis of the lowest value of root mean square error (RMSE) [39]. The Gaussian model is defined by the equation:

$$
\gamma_{(k)}=C_{0}+C \cdot\left[1-\exp \left(\frac{-3 k^{2}}{a^{2}}\right)\right]
$$

...where: $C_{0}$ is the random variable (nugget), $C$ is the systematic variable, and $a$ is the time correlation range. The nugget semivariance expressed as a percentage of the total semivariance enables comparison of the relative size of the nugget effect among water table depths.
We used this ratio and the classification according to Cambardella et al. [40] to define distinct classes of temporal dependence of the water table depths.

Apart from geostatistical methods, statistical and fractal analyses were used in order to determine similarities and differences of the temporal variability of water table depths in topohydrosequence. The fractal dimension (D) was obtained from the equation $\mathrm{D}=(4-\mathrm{S}) / 2$ [41], where $\mathrm{S}$ is the absolute value of the slope of the regression line of log semivariance vs. log time range for each well. Joining cluster analysis (CA) and multiple regression analysis (MR) were also applied. In order to check which of the applied parameters characterizing temporal variability in the water table depths are dependent on soil location in a relief we used PCA and factor analysis (FA).The mathematical and statistical calculations were performed using Statistica 10.0 software.

\section{Results and Discussion}

Fig. 3 shows the temporal variability of water table fluctuation and precipitation on the investigated topohydrosequence. At the beginning of 1993 the water table in Retisols located at the summit of the slope reached the lowest level (below $400 \mathrm{~cm}$ ) throughout the period of measurements. The low levels in 1993 were caused by lower precipitation in 1992, which made only $64 \%$ of the mean annual precipitation for long-term observations. Also, in 2005 the water table close to $400 \mathrm{~cm}$ below surface was observed, although the amount of precipitation in 2005 was $101 \%$ of long-term mean annual precipitation. This suggests that the water table in a given year is determined not only by weather conditions in a given year, but also by the weather conditions from previous years. Precipitation was significantly lower in 2003 and 2004

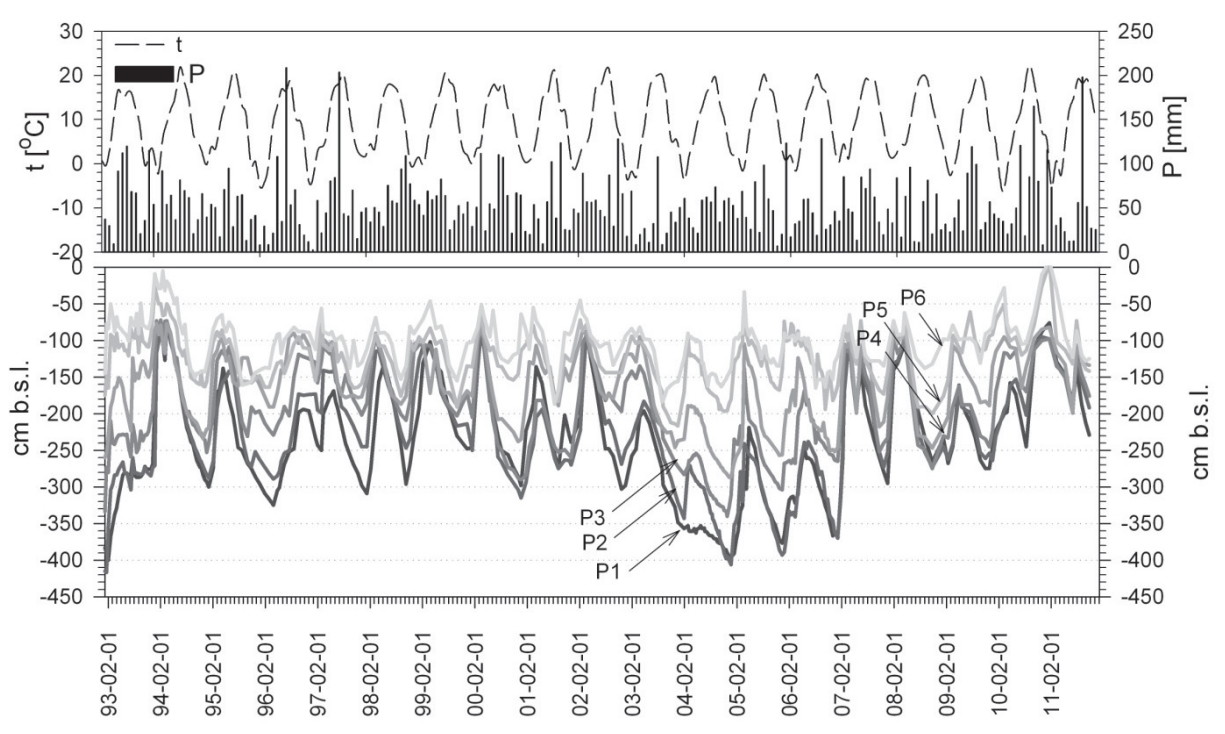

Fig. 3. Temporal changes in water table depth in soil of topohydrosequence in relation to precipitation $(\mathrm{P})$ and temperature (t). 
Table 1. Linear relationship between the mean annual water table depth and precipitation in given and previous years.

\begin{tabular}{|c|c|c|c|c|}
\hline Slope element & $\begin{array}{c}\text { Soil } \\
\text { - well }\end{array}$ & $\begin{array}{c}\text { Elevation of well } \\
\text { m a.s.l. }\end{array}$ & Linear regression & $\begin{array}{c}\text { Correlation } \\
\text { coefficient } \mathrm{r}\end{array}$ \\
\hline Summit & P1 & 89.67 & MAWT $=-740+0.32 \mathrm{P}+0.45 \mathrm{Pp}$ & 0.89 \\
\hline Summit & P2 & 88.85 & MAWT $=-682+0.31 \mathrm{P}+0.39 \mathrm{Pp}$ & 0.82 \\
\hline Shoulder & P3 & 88.16 & MAWT $=-508+0.22 \mathrm{P}+0.27 \mathrm{Pp}$ & 0.72 \\
\hline Pediment & P4 & 86.44 & MAWT $=-348+0.15 \mathrm{P}+0.14 \mathrm{Pp}$ & 0.67 \\
\hline Footslope & P5 & 85.14 & MAWT $=-222+0.11 \mathrm{P}$ & 0.73 \\
\hline Footslope & P6 & 84.56 & MAWT $=-213+0.14 \mathrm{P}$ & 0.87 \\
\hline
\end{tabular}

MAWT - mean annual water table depth, $\mathrm{P}$ - total precipitation at given year, $\mathrm{P}_{\mathrm{p}}$ - total precipitation at previous year

than the long-term mean annual precipitation. This conclusion seems to be confirmed by multiple regression (Table 1). The mean annual water table depth in the soils occupying a higher location in the relief (P1, P2, and P3) was determined by the precipitation from a given year (P) and from the previous year (Pp). But in these soils the precipitation from the previous $\left(\mathrm{P}_{\mathrm{p}}\right)$ year had greater impact on the mean annual water table depth than that from a given year (P), which was supported by the regression coefficient values higher for $\mathrm{P}_{\mathrm{p}}$ than for $\mathrm{P}$. Also, $\mathrm{P}$ and $\mathrm{P}_{\mathrm{p}}$ determined the water table depth of Gleyic Cambic Phaeozems located at the pediment of a topohydrosequence (well P4). The impact of the precipitation from the previous year on the water table in Gleysols situated within the footslope was statistically insignificant $\left(\mathrm{P}_{\mathrm{p}}^{*}\right)$. So, the lower the location of soil in topohydrosequence, the smaller the impact of precipitation from the previous year on the mean annual water table depth. Lutz et al. [5] and Liang et al. [42] have reported that it is difficult to find a direct relationship between precipitation and the groundwater level because of the complex factors determining the groundwater depth. In our study low values of the regression coefficient were obtained taking into account the relationship between precipitation and water table depth only. In this study, attention was paid to obtain a general relationship between annual precipitation and mean annual water table depth. Cai and Ofterdinger [2] in their study, have observed rapid interaction between the rainfall events and groundwater depth. Fistikoglu et al. [10] have studied the effect of rainfall intensity on the groundwater level and Almedeij and Al-Ruwaih [9] have found a relationship between the climatological parameters such as rainfall and temperature and groundwater level. Aflatooni and Mardaneh [1] analyzing, annual precipitation and its relationship to groundwater level variation, have found that the average annual groundwater level is positively correlated to annual precipitation with a certain time delay.

Both the depth of the water table and its amplitude were determined by the location of soil in the relief (Fig. 3). The mean water table depth (MWT), the mean high water table depth (MHWT), and the mean low water table depth (MLGL) were deeper in the soils at the summit of the slope in comparison to those located in the footslope (Table 2). The MWTs in Retisols and Luvisols were 250, 238, and $199 \mathrm{~cm}$ below surface level, respectively, for $\mathrm{P} 1, \mathrm{P} 2$, and $\mathrm{P} 3$, whereas in Phaeozems and Gleysols the corresponding values were at depths of 167 (P4), 127 (P5), and 105 (P6) cm. The highest fluctuations of observed water table were in P1 wells, whereas the lowest were in P6 pedon. These patterns are explained as a function of the lateral flow of water from upslope to downslope. Fan [15] and Kozłowski Komisarek [16] have pointed out that the amplitude and the depth of the water table depth depends on the

Table 2. Mean water table depth (MWT), mean high water table depth (MHWT), mean low water table depth (MLWT), the highest observed water table depth (THWT), and the lowest observed water table depth (TLWT) in the wells of topohydrosequence.

\begin{tabular}{|c|c|c|c|c|c|c|c|}
\hline \multirow{2}{*}{ Parameters } & \multirow{2}{*}{ Unit } & \multicolumn{6}{|c|}{ Wells } \\
\hline & & P1 & $\mathrm{P} 2$ & $\mathrm{P} 3$ & $\mathrm{P} 4$ & P5 & P6 \\
\hline MWT & \multirow{5}{*}{ cm b.s.l. } & -249.8 & -237.6 & -198.7 & -166.5 & -126.9 & -105.0 \\
\hline MHWT & & -171.6 & -168.4 & -134.4 & -105.8 & -81.1 & -63.0 \\
\hline MLWT & & -322.9 & -310.9 & -256.4 & -221.7 & -172.6 & -149.4 \\
\hline THWT & & -79.0 & -82.0 & -72.0 & -77.0 & -27.0 & -5.0 \\
\hline TLWT & & -400.0 & -417.0 & -340.0 & -287.0 & -217.0 & -187.0 \\
\hline
\end{tabular}

b.s.l. - below surface level 
Table 3. Matrix of the p-value (statistical significance) of Tukey's honestly significant difference test of the mean water table depths in the wells of topohydrosequence.

\begin{tabular}{|c|c|c|c|c|c|c|}
\hline Wells & P1 & P2 & P3 & P4 & P5 & P6 \\
\hline P1 & & & & & & \\
\hline P2 & $3,30 \mathrm{E}-01$ & & & & & \\
\hline P3 & $2,03 \mathrm{E}-05$ & $2,03 \mathrm{E}-05$ & & & & \\
\hline P4 & $2,03 \mathrm{E}-05$ & $2,03 \mathrm{E}-05$ & $2,19 \mathrm{E}-05$ & & & \\
\hline P5 & $2,03 \mathrm{E}-05$ & $2,03 \mathrm{E}-05$ & $2,03 \mathrm{E}-05$ & $2,03 \mathrm{E}-05$ & & \\
\hline P6 & $2,03 \mathrm{E}-05$ & $2,03 \mathrm{E}-05$ & $2,03 \mathrm{E}-05$ & $2,03 \mathrm{E}-05$ & $4,31 \mathrm{E}-03$ & \\
\hline
\end{tabular}

Table 4. Matrix of the correlation coefficient of the water table depths in the wells of topohydrosequence.

\begin{tabular}{|c|c|c|c|c|c|c|}
\hline Wells & P1 & P2 & P3 & P4 & P5 & P6 \\
\hline P1 & & & & & & \\
\hline P2 & 0.92 & & & & & \\
\hline P3 & 0.83 & 0.93 & & & & \\
\hline P4 & 0.76 & 0.78 & 0.83 & & & \\
\hline P5 & 0.59 & 0.53 & 0.59 & 0.71 & & \\
\hline P6 & 0.54 & 0.50 & 0.56 & 0.64 & 0.91 & \\
\hline
\end{tabular}

location of wells in the drainage soil sequence. Natural soil drainage is a consequence of the soil position within topohydrosequence [14].

On the basis of variance analysis (ANOVA) and Tukey's tests, except for P1 vs. P2, significant differences between the mean values of the water table depth (MWT) in the studied wells were observed (Table 3). Despite these differences, statistically significant similarities in the course of the temporal changes of water table depth in individual wells were noted (Table 4). The strongest similarities (the highest

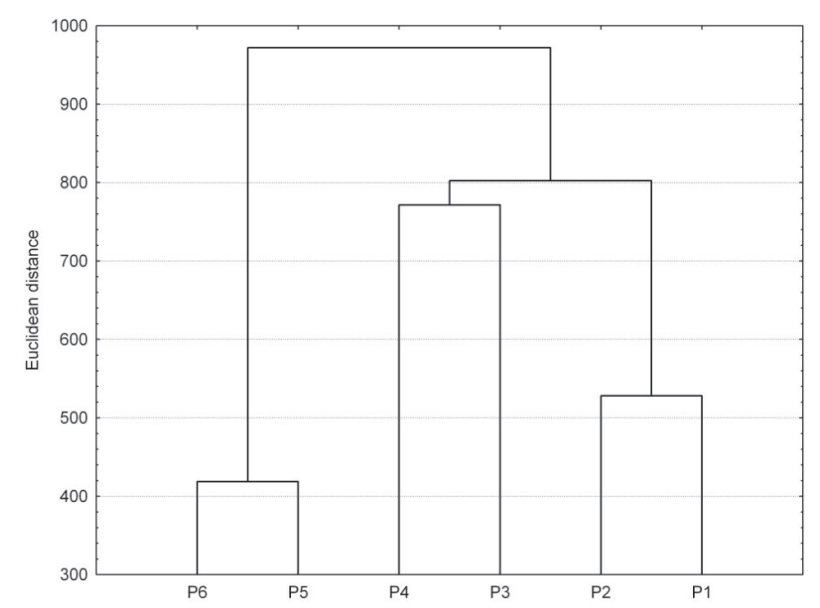

Fig. 4. Dendrogram of hierarchical cluster analysis of the water table depths in the wells of topohydrosequence. correlation coefficient) were between neighbouring wells. Wells P1 and P2 are characterized by a similar course of water table depths and make a separate cluster with the Euclidean distance of 435 (Fig. 4). The water table depths from P3 and P4 make another cluster, and still another one is made by the water table depths from P5 and P6.

Fig. 5 shows the semivariograms of the temporal water table changes within the topohydrosequence studied. Studies using geostatistics for temporal variability analysis of groundwater and water table depths have been reported by Triki et al. [23], Ahmadi and Sedghamiz [29], and $\mathrm{Ta}^{\prime}$ any et al. [31]. Small values of RMSE (from 0.046 to 0.071 ) presented in Table 4 indicated that the Gaussian model was the most appropriate semivariogram matching to the experimental data. From the presented semivariograms (Fig. 5) and their parameters (Table 5), it follows that temporal changes in water table depth are characterized by high values of systematic variability and small values of random variability (nugget effect). This systematic temporal structure is connected with the regular cycles of the water table reconstruction in autumn-spring period and summer dropping. Very low nugget effects indicate that the temporal changes in the water table depths were temporarily correlated and exhibit strong temporal dependence. Low values of nuggets in sill have been monitored by Triki et al. [23], Ahmadi and Sedghamiz [29], and $\mathrm{Ta}^{\prime}$ any et al. [31]. The contribution of the nugget effect $\left(\mathrm{C}_{0}\right)$ to sill were from $3.5 \%$ for $\mathrm{P} 1$ pedon to $6.6 \%$ for $\mathrm{P} 6$ well, so the lower the position of soil within topohydrosequence the greater the contribution of the nugget effect to the sill. Also, the range of time correlation was shorter in soils, which were located in the lower part of the relief. These ranges were 197, 194, 191, 183, 177, and 172 days, respectively, for the $\mathrm{P} 1, \mathrm{P} 2, \mathrm{P} 3, \mathrm{P} 4, \mathrm{P} 5$, and $\mathrm{P} 6$ wells. For the groundwater of Darab Plain in southern Iran, Ahmadi and Sedghamiz [29] found that the average time correlation range was 7.2 months and, according to $\mathrm{Ta}^{\prime}$ any et al. [31], this time was from a few to more than 20 months (3-21 months). Values of the time correlation range obtained in this study indicate that on the one hand it is possible to monitor the water table depth in longer time intervals, but on the other hand 


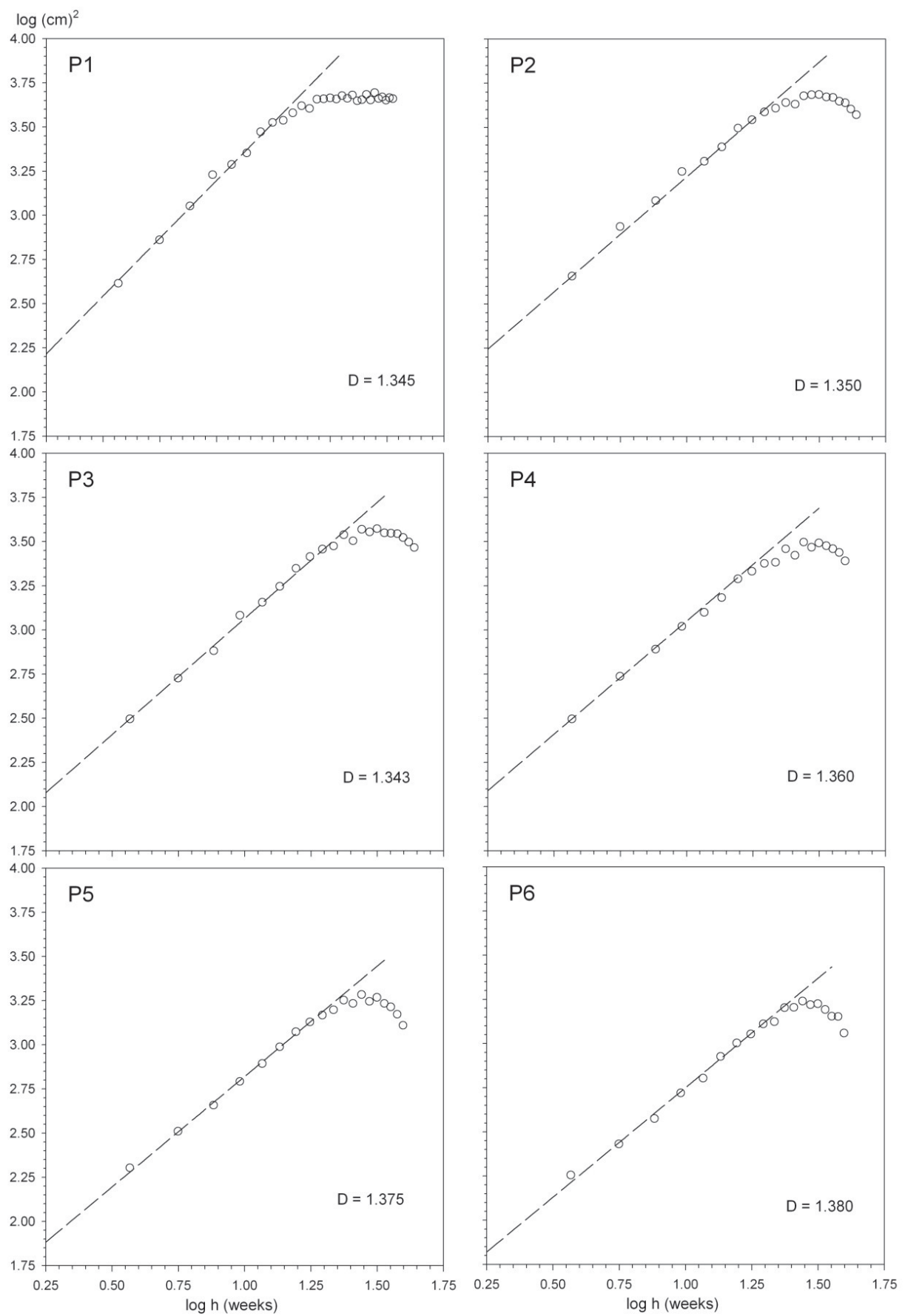

Fig. 5. Semivariograms of temporal variability of the water table and its fractal dimensions (D).

Table 5. Properties of the fitted variograms of the temporal variability the water table.

\begin{tabular}{|c|c|c|c|c|c|}
\hline Well no, & $\mathrm{C}_{0}\left(\mathrm{~cm}^{2}\right)$ & $\mathrm{C}\left(\mathrm{cm}^{2}\right)$ & $\begin{array}{c}\mathrm{a} \\
(\text { weeks })\end{array}$ & $\begin{array}{c}\mathrm{C}_{\mathrm{o}} / \text { sill } \\
(\%)\end{array}$ & RMSE \\
\hline P1 & 166.3 & $4,554.7$ & 28.19 & 3.5 & 0.057 \\
\hline P2 & 185.0 & $4,750.0$ & 27.70 & 3.7 & 0.046 \\
\hline P3 & 145.0 & $3,470.7$ & 27.25 & 4.0 & 0.070 \\
\hline P4 & 130.0 & $2,880.0$ & 26.12 & 4.3 & 0.071 \\
\hline P5 & 103.7 & $1,632.0$ & 25.29 & 6.0 & 0.051 \\
\hline P6 & 95.0 & $1,336.9$ & 24.60 & 6.6 & 0.067 \\
\hline
\end{tabular}

the temporal intervals depend on well location within the topohydrosequence. Ahmadi and Sedghamiz [29] have reported that the wells with low fluctuations of groundwater levels could be monitored in longer time intervals. In the topohydrosequence we studied, the lowest fluctuations - and, simultaneously, the shorter range of the time correlation - were observed in the P6 pedon. In this respect, the range of temporal correlation should be taken into account for monitoring decisions and not the fluctuations of the water table. In well P1 the water table depths were temporally correlated for 197 days, whereas in P6 it was 172 days. This indicates that the water table response to water inflow, as well 


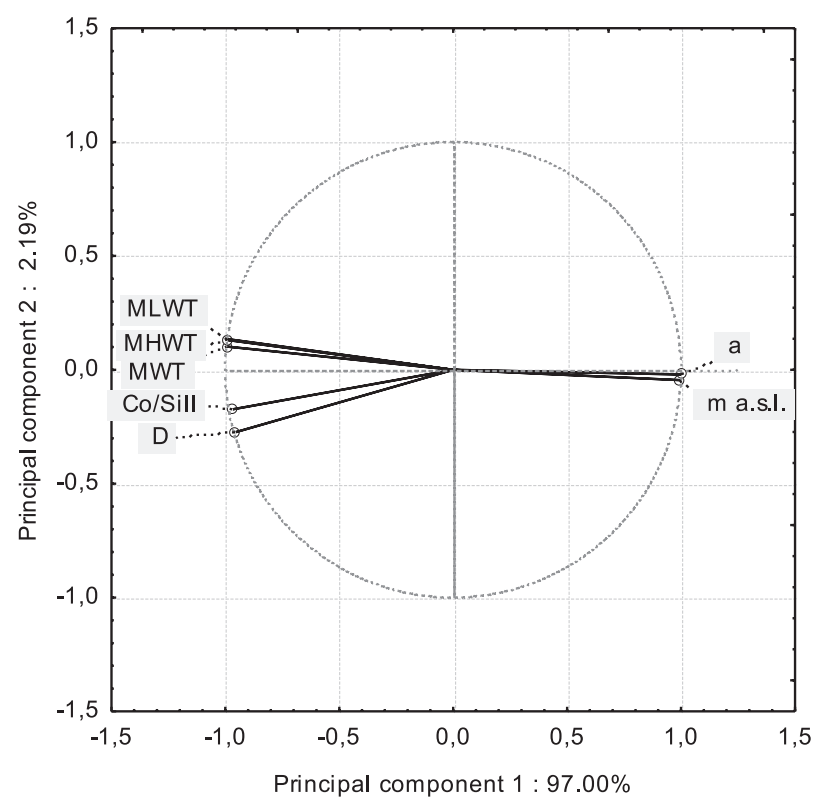

Fig. 6. Result of the PCA: a - time correlation range of water table, MWT - mean water table depth, $\mathrm{m}$ a.s.l. - location of piezometers within toposequence in meters above sea level, MLWT - mean lower water table depth, MHWT - mean higher water table depth, $\mathrm{C}_{\mathrm{o}} / \mathrm{sill}$ - ratio of random variability to sill, $\mathrm{D}$ - fractal dimension.

as water outflow in well P1 was on average 4 weeks delayed in comparison to the water table response in P6. Semivariograms of the temporal water table depth variability presented in Fig. 5 allowed us to calculate the fractal dimension (D).

The relatively small range of the estimated D values showed that there were distinct similarities in the dynamics of the water table in the wells investigated. The values of D ranged from 1.346 to 1.350 in wells located in the summit of the slope (P1 and P2) and from 1.353 to 1.360 for P3 and P4 wells, whereas in soils of the footslope (P5 and P6) they ranged from 1.365 to 1.370. The values of $\mathrm{D}$ calculated in this study were

Table 6. Matrix of factor loadings (VF1, VF2) calculated on the basis of used statistical and geostatistical parameters used for characterizing the variability of the water table in topohydrosequence.

\begin{tabular}{|c|c|c|}
\hline Parameter & VF1 & VF2 \\
\hline MWT & -0.994 & 0.110 \\
\hline MHWT & -0.989 & 0.143 \\
\hline MLWT & -0.990 & 0.139 \\
\hline $\mathrm{a}$ & 0.997 & -0.026 \\
\hline Co/Sill & -0.973 & -0.160 \\
\hline D & -0.957 & -0.270 \\
\hline Variance $\%$ & 96.69 & 2.52 \\
\hline Cumulative variance $\%$ & 96.69 & 99.21 \\
\hline
\end{tabular}

similar to those obtained by Rakhshandehroo and Amiri [26] and $\mathrm{Yu}$ et al. [27] by the detrended fluctuation analysis (DFA) method. Despite the fact that the D values vary over a short range, a distinct correlation was found between the value of $\mathrm{D}$ and the soil location in the topohydrosequence. Yu et al. [27] reported that different values of the fractal scaling coefficients at different wells might be due to many factors such a anthropogenic perturbations, precipitation, elevation, and particularly the high heterogenic hydrogeological conditions.

As follows from the data presented in Fig. 6, the two principal components explain over $99 \%$ variation of the parameters analyzed, moreover, one principal component explained nearly $97 \%$ of the variation. All statistical and geostatistical parameters characterizing variability in the water table depth were strongly (either positively or negatively) correlated with the first principal component, which was confirmed by factor analysis (Table 6). The first factor (VF1) was strongly correlated with all parameters used. The second factor (VF2) explained only $2.52 \%$ of total variance. It was most likely that VF1 represented the soil location in topohydrosequence. The values of the time correlation range of the water table changes were positively correlated with the VF1, which indicates that the higher the location of the well in the topohydrosequence, the longer the range of time correlation. The other parameters, i.e., MWT, MLWT, MHWT, $\mathrm{C}_{0} /$ sill, and D, were negatively correlated with VF1.

On the basis of MWT, MLWT, MHWT, $\mathrm{C}_{0} / \mathrm{sill}$, and D using PCA analysis, the wells were grouped into 3 separate sets (Fig. 7). As in the case of cluster analysis, the results describing the water table in wells P1 and P2 made one group. Separate sets were made by P3 and P4 wells and P5 and P6 wells. This result

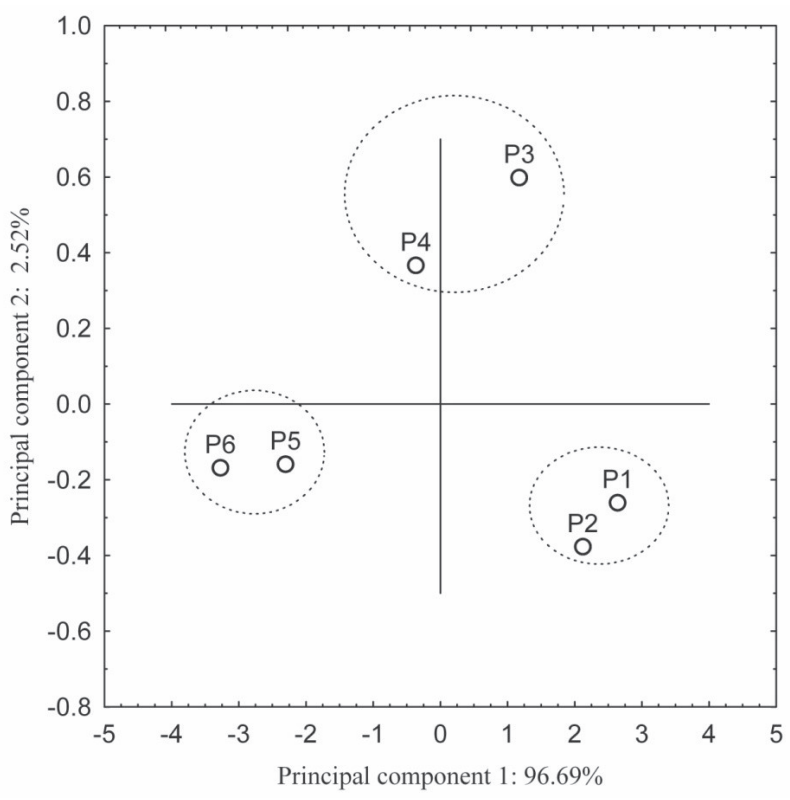

Fig. 7. Result of the PCA for wells calculated on the basis of the MWT, MHWT, MLWT, a, Co/C, and D. 
indicates that within the topohydrosequence studied it is possible to reduce the number of wells for monitoring. Triki et al. [23] and Brito Neto et al. [24] have also used PCA and CA to determine groupings of hydrologic measurement stations on different temporal scales.

\section{Conclusions}

We studied temporal variability of the water table fluctuations in a topohydrosequence in 1993-2012. Statistical and geostatistiacl techniques were applied in this study. Some important conclusions and findings of the present study are:

- The mean annual water table depth in soils occupying higher location in a relief is determined by precipitation at a given and previous year but in soils at the footslope only by precipitation at a given year. The lower the position of soil in the topohydrosequence, the smaller the effect of precipitation from the previous year on mean water table depth.

- The mean water table depth, the mean high water table depth, the mean low water table depth, and their fluctuations depend on soil location within the topohydrosequence.

- The water table fluctuations are characterized by a distinct temporal structure and low values of random variability (nugget effect). The contribution of nugget effect in variance depends on the location of wells on the slope. Also, the range of time correlation depends on a relief and is shorter in soils that are situated in lower parts of the topohydrosequence and is longer in wells in its higher parts.

- A relatively small range of fractal dimension (D) of temporal water table variability revealed that there are distinct similarities in the dynamics of water table depths in the wells of the slope. Despite the fact that the values of D are slightly different, there is a distinct correlation between the values of $\mathrm{D}$ and the location of soil in the topohydrosequence.

- The values of multivariate analysis indicate that the statistical and geostatistical parameters applied to assess temporal variability of water table depth are dependent on the soil (well) location in the relief. Moreover, multivariate analyses can be used to determine the groups of measurement stations (wells), which are characterized by similar dynamics of water table changes.

\section{References}

1. AFLATOONI M., MARDANEH M. Time series analysis of groundwater table fluctuations due to temperature and rainfall change in Shiraz plain. International Journal of Water Resources and Environmental Engineering, 3 (9), 176, 2011.

2. CAI Z., OFTERDINGER U. Analysis of groundwaterlevel response to rainfall and estimation of annual recharge in fractured hard rock aquifers, NW Ireland. Journal of Hydrology, 535, 71, 2016.

3. JAN C.-D., CHEN T.-H., HUANG H.-M. Analysis of rainfall-induced quick groundwater-level response by using a Kernel function. Paddy and Water Environment, 11, 135, 2013.

4. LORENZO-LACRUZ J., GARCIA C., MORÁN-TEJEDA E. Groundwater level responses to precipitation variability in Mediterranean insular aquifers. Journal of Hydrology, 552, 516, 2017.

5. LUTZ A., MINYILA S., SAGA B., DIARRA S., APAMBIRE B., THOMAS J. Fluctuation of Groundwater Levels and Recharge Patterns in Northern Ghana. Climate, 3, 1, 2015.

6. MACHIWAL D., JHA M.K. Characterizing rainfallgroundwater dynamics in a hard-rock aquifer system using time series, geographic information system and geostatistical modelling. Hydrological Processes, 28 (5), 2824-2843, 2014.

7. NOWICKA E. , OLSZEWSKA B., KOPAŃCZYK K., KLIMCZAK H., PŁYWACZYK L. Evaluation of variability of groundwater level using the gradient vector field. Inżynieria Ekologiczna, 39, 105, 2014 [In Polish].

8. SHI X., VAZE J., CROSBIE R. The controlling factors in the daily and monthly groundwater recharge estimation using the water table fluctuation method. In $36^{\text {th }}$ Hydrology and Water Resources Symposium: The art and science of water. Engineers Australia, 725, 2015.

9. ALMEDEIJ J., AL-RUWAIH F. Periodic behavior of groundwater level fluctuations in residential areas. Journal of Hydrology, 328, 677, 2006.

10. FISTIKOGLU O., GUNDUZ O., SIMSEK C. The correlation between statistically downscaled precipitation data and groundwater level Records in North-Western Turkey. Water Resources Management, 30 (15), 5625, 2016.

11. HUMPHREY C.P., HARRIS J., O'DRISCOLL M.A. Evaluation of water table dynamics in relation to soil morphological indicators of seasonal wetness. Universal Journal of Environmental Research \& Technology, 2 (4), 286, 2012.

12. KOZŁOWSKI M., KOMISAREK J. Deficiencies of readily plant available water in selected Albeluvisols in central Wielkopolska. Nauka Przyroda Technologie, 8 (1), 4, 2014 [In Polish].

13. LAFARE A.E.A, PEACH D.W., HUGHES A.G. Use of seasonal trend decomposition to understand groundwater behaviour in the Permo-Triassic Sandstone aquifer, Eden Valley, UK. Hydrogeology Journal, 24 (1), 141, 2016.

14. BUOL S.W., SOUTHARD R.J., GRAHAM R.C., MCDANIEL P.A. Soil genesis and classification: WileyBlackwell, 2011.

15. FAN Y. Groundwater in the Earth's critical zone: relevance to large-scale patterns and processes. Water Resources Research, 51, 3052, 2015.

16. KOZŁOWSKI M., KOMISAREK J. Temporal variability of selected dissolved components content in groundwater of the catena system of Poznań Lakeland. Rocz. Ochr. Środ., 15, 1965, 2013 [In Polish].

17. KOZŁOWSKI M., KOMISAREK J. Groundwater chemistry and hydrogeochemical processes in a soil catena of the Poznan Lakeland, central Poland. Journal of Elementology, 22 (2), 681, 2017.

18. CALZOLARI C., UNGARO F. Predicting shallow water table depth at regional scale from rainfall and soil data. Journal of Hydrology, 414, 374, 2012. 
19. NOWICKA E., OLSZEWSKA B., PŁYWACZYK L., ŁYCZKO W. Changes of ground water levels in the Oder valley below the stage of water fall in Brzeg Dolny in the years 1971-2012. Acta Scientiarum Polonorum. Formatio Circumiectus, 14 (1), 169, 2015a [in Polish].

20. NOWICKA E. DĄBEK P. OLSZEWSKA B. ŻMUDA $R$. Analysis of spatial changes in groundwater retention for the Oder valley in the Malczyce region. Inżynieria Ekologiczna, 44 (40-46), 2015b [In Polish].

21. TABARI H., NIKBAKHT J., SOME'E B.S. Investigation of groundwater level fluctuations in the north of Iran. Environmental Earth Sciences, 66, 231, 2012.

22. ZIMMERMANN I., FLEIGE H., HORN R. Longtime effects of deep groundwater extraction management on water table levels in surface aquifers. Journal of Soils and Sediments, 17 (1), 133, 2017.

23. TRIKI I., TRABELSI N., HENTATI I., ZAIRI M. Groundwater levels time series sensitivity to pluviometry and air temperature: a geostatistical approach to Sfax region, Tunisia. Environmental Monitoring and Assessment, 186 (3), 1593, 2014.

24. DE BRITO NETO R.T., SANTOS C.A.G., MULLIGAN K., BARBATO L. Spatial and temporal water-level variations in the Texasportion of the Ogallala Aquifer. Natural Hazards, 80, 351, 2015.

25. LITTLE M.A., BLOOMFIELD J.P. Robust evidence for random fractal scaling of groundwater levels in unconfined aquifers. Journal of hydrology, 393 (3), 362, 2010.

26. RAKHSHANDEHROO G.R., AMIRI S.M. Evaluating fractal behavior in groundwater level fluctuations time series. Journal of hydrology, 464, 550, 2012.

27. YU X., GHASEMIZADEH R., PADILLA I.Y., KAELI D., ALSHAWABKEH, A. Patterns of temporal scaling of groundwater level fluctuation. Journal of Hydrology, 536, 485, 2016.

28. ADHIKARY P.P., DASH C.J. Comparison of deterministic and stochastic methods to predict spatial variation of groundwater depth. Applied Water Science, 7 (1), 339, 2017.

29. AHMADI S.H., SEDGHAMIZ A. Geostatistical analysis of spatial and temporal variations of groundwater level. Environmental Monitoring and Assessment, 129, 277, 2007.

30. DELBARI, M., MOTLAGH M.B., AMIRI M. Spatiotemporal variability of groundwater depth in the Eghlid aquifer in southern Iran. Earth Sciences Research Journal, 17 (2), 105, 2013.

31. TA'ANY R.A., TAHBOUB A.B, SAFFARINI G.A. Geostatistical analysis of spatiotemporal variability of groundwater level fluctuations in Amman-Zarqa basin, Jordan: a case study. Environmental Geology, 57, 525, 2009.

32. RAN Y., LI X., GE Y., LU X., LIAN Y. Optimal selection of groundwater-level monitoring sites in the Zhangye Basin, Northwest China. Journal of Hydrology, 525, 209, 2015.

33. MARCINEK J., KOMISAREK J. Anthropogenic transformations of soils of Poznań Lakeland as a results of intensive agricultural farming. AR. Poznań, 2004 [In Polish].

34. HALL, G.F. Pedology and geomorphology. In: Wilding, L.P., Smeck, N.E., Hall, G.F. (Eds.), Pedogenesis and Soil Taxonomy: I. Concepts and Interactions. Elsevier, Amsterdam, 117, 1983.

35. SOIL SCIENCE DIVISION STAFF. SOIL SURVEY MANUAL. Ditzler C., Scheffe K., Monger H.C. (Eds.). USDA Handbook 18. Government Printing Office, Washington, D.C., 2017.

36. IUSS W. World Reference Base for Soil Resources 2014, update 2015. International soil classification system for naming soils and creating legends for soil maps. World Soil Resources Reports, 2015.

37. WARRICK A.W., MYERS D.E., NIELSEN D.R. Geostatistical methods applied to soil science. Methods of Soil Analysis: Part 1-Physical and Mineralogical Methods, 53, 1986.

38. Tilke C. VARIOWIN-Software for Spatial Data Analysis in 2D: Pannatier, Yvan 1996: Springer Verlag, 91 p., ISBN: 0-387-94679-9, Hardcover DM 78.00. Computational Statistics \& Data Analysis, 25, 243, 1997.

39. LOAGUE K., GREEN R.E. Statistical and graphical methods for evaluating solute transport models: overview and application. Journal of Contaminant Hydrology, 7, 51, 1991.

40. CAMBARDELLA C.A, MOORMAN T.B., PARKIN T.B, KARLEN D.L., NOVAK J.M., TURCO R.F, KONOPKA A.E. Field-scale variability of soil properties in central Iowa soils. Soil Science Society of America Journal, 58, 1501, 1994.

41. EGHBALL B., HERGERT G.W., LESOING G.W., FERGUSON R.B. Fractal analysis of spatial and temporal variability. Geoderma, 88, 349, 1999.

42. LIANG X., ZHANG Y.K., SCHILLING K. Effect of heterogeneity on spatiotemporal variations of groundwater level in a bounded unconfined aquifer. Stochastic Environmental Research and Risk Assessment, 30 (1), 1, 2016. 